\title{
Effects of Sand and Straw Bedding on the Lying Behavior, Cleanliness, and Hoof and Hock Injuries of Dairy Cows
}

\author{
M. Norring, ${ }^{\star 1}$ E. Manninen, ${ }^{\star}$ A. M. de Passillé, $†$ J. Rushen, $\dagger$ L. Munksgaard,‡ and H. Saloniemi* \\ *Department of Production Animal Medicine, University of Helsinki, 00014 Helsinki, Finland \\ †Pacific Agrifood Research Centre, Agriculture and Agri-Food Canada, PO 10006947 Highway 7, Agassiz, BC, Canada, V9M 1A0 \\ ‡Faculty of Agricultural Sciences, Aarhus University, PO Box 50, DK-8830 Tjele, Denmark
}

\section{ABSTRACT}

This experiment compared the effects of sand and straw bedding in free stalls on resting time, cleanliness, hock injuries, and hoof health of dairy cows and tested whether cow preferences for a bedding material depended on the familiarity with the material. A total of 52 dairy cows were kept either on straw bedded concrete stalls or sand stalls for at least $21 \mathrm{wk}$. The lying behavior was observed, and hock lesions, hoof health, and cleanliness of the cows and stalls were measured. A 5$\mathrm{d}$ preference test between sand and straw stalls was conducted at the end of the experiment. The total daily duration of lying was longer for cows on straw bedding than on sand bedding (straw $749 \pm 16$ vs. sand $678 \pm$ $19 \mathrm{~min}$ ). During the preference test, cows that had been kept on straw bedding preferred lying in straw stalls [straw 218.7 (133.4 to 239.7$)$ vs. sand $9.0 \mathrm{~min}$ (2.8 to 44.8)]; however, cows that had been kept on sand showed no preference [straw 101.3 (51.7 to 205.9) vs. sand $94.3 \mathrm{~min}$ (54.1 to 156.1 , median and interquartile range)]. Although there were no differences in the dirtiness of stalls, the cows using straw stalls were dirtier than cows using sand stalls [straw 6.04 (5.39 to 6.28) vs. sand 4.19 (3.62 to 5.16)]. At the end of experiment the severity of hock lesions was lower for cows on sand than for cows on straw [sand 0.5 (0.0 to 1.0) vs. straw 1.0 (1.0 to 2.0)]. The improvement in overall hoof health over the observation period was greater for cows kept on sand compared with cows kept on straw [sand -2.00 $(-3.75$ to -0.25$)$ vs. straw 0.00 ( -2.00 to 2.00$)]$. Straw bedding increased the time that cows spend lying, and cows preferred straw stalls to sand stalls. However, previous experience with sand reduces avoidance of sand stalls. Sand stalls were advantageous for cow cleanliness and health; hock lesions and claw diseases

Received June 15, 2007.

Accepted October 17, 2007.

${ }^{1}$ Corresponding author: Marianna.norring@helsinki.fi healed more quickly for cows using sand stalls compared with straw.

Key words: cow, injury, behavior, lying

\section{INTRODUCTION}

Dairy cows can prioritize resting over other behaviors (Munksgaard et al., 2005), and cows that are prevented from lying down show behavioral and physiological stress responses (Munksgaard and Simonsen, 1995; Fisher et al., 2002). Reduced time spent lying and increased time spent standing on concrete was associated with reduced claw health (Singh et al., 1993a), and the duration of time cows spend lying was suggested as an indictor of welfare and cow comfort (Herlin, 1997).

The amount of time cows spend lying down depends, among other things, on the bedding material provided. Cows show a preference for lying on softer materials (Manninen et al., 2002; Tucker and Weary, 2004) and lie down longer on soft materials (Chaplin et al., 2000b; Haley et al., 2001; Rushen et al., 2007). Straw is commonly used as bedding material because it provides both softness and thermal insulation (Tuyttens, 2005), but mastitis-causing pathogens proliferated in straw and sawdust (Ward et al., 2002; Zdanowicz et al., 2004), which has led to an increased use of sand in free-stall housing. Use of sand stalls was associated with a reduced prevalence of lameness (Cook, 2003; Espejo et al., 2006). Cook (2003) suggested that a greater willingness of cows to use sand stalls may be a reason for improved hoof health.

Nevertheless, despite these long-term advantages for cattle health, Manninen et al. (2002) showed that cows had a strong preference for straw bedding over sand and rarely chose to rest on sand. In part, this may have reflected their lack of familiarity with sand; Tucker et al. (2003) found that cows previously housed on sawdust preferred sawdust stalls and cows previously housed with sand stalls used sawdust and sand stalls equally.

We examined the effect of sand bedding on resting time, cleanliness, and hoof health of dairy cows and tested whether their preference for straw over sand 
depended on their familiarity with the material in 2 experiments.

\section{MATERIALS AND METHODS}

\section{Animals and Housing}

A total of 52 Friesian dairy cows with a BW of 663 $\pm 81 \mathrm{~kg}$ (mean $\pm \mathrm{SD})$ were used. Due to the distribution of calvings throughout the year, 36 cows were lactating (DIM $116 \pm 41$ ) at the beginning of the experiment, whereas the remaining 16 were nonlactating pregnant cows (50 $\pm 23 \mathrm{~d}$ before calving). Seventeen of the cows were primiparous, and 35 cows were multiparous (parity $3.34 \pm 1.26$; range 2 to 7 ). During the previous lactation, the milk production of the multiparous cows was $7,855 \pm 1,661 \mathrm{~kg}$ and SCC was 121,000 $\pm 84,000$ cells/ $\mathrm{mL}$. Before and during the experiment, the cows were fed grass silage (DM 23 to 36\%) to ad libitum intake, and concentrates (from barley, oats, rapeseed meal, and molasses, CP 15 to 17\%) from an automatic feeder. The milk production of the cows was measured once monthly, and the amount of concentrates was adjusted to the milk yield according to Finnish regimens (http:// www.agronet.fi/rehutaulukot). Water was available ad libitum. Cows were milked twice daily.

Before the experiment, the cows had been housed in an insulated or an uninsulated barn with concretebased stalls with hard rubber mats and softer mats and mattresses bedded with a mixture of peat and cut straw on them. During summer the cows were on pasture.

\section{Experiment 1}

Procedures. The cows were semirandomly divided into 6 groups with 2 groups each with 12 cows (yr 1), 2 groups each with 9 cows (yr 2), and 2 groups each with 5 cows (yr 3). The groups were balanced for the proportion of lactating cows and nonlactating cows, DIM or days before expected calving, previous milk production, BW, and parity.

Each year, one of the groups was housed with stalls containing sand, whereas the other group was housed with stalls with deep straw bedding. In the straw stalls, about $6.5 \mathrm{~kg}$ of cut barley straw was put on the concrete floor at the beginning of the experiment and about 0.7 $\mathrm{kg}$ of new straw added every day. In the sand stalls, about $20 \mathrm{~cm}$ layer of fine sand $(0.1$ to $0.6 \mathrm{~mm})$ was placed on the sand base, which consisted of particles of different sizes. No organic bedding was used in sand stalls. The stalls were cleaned and leveled twice daily. The stall length was $248 \mathrm{~cm}$ where $204 \mathrm{~cm}$ was available for lying and the rest was head space; the stall width was $120 \mathrm{~cm}$. Neck rails were positioned $163 \mathrm{~cm}$ from back part of the stalls at the height of $110 \mathrm{~cm}$. The stalls had a $29-\mathrm{cm}$ curb. The stall design is illustrated in Manninen et al. (2002).

The 2 types of stalls were in 2 separate rooms in an unheated, uninsulated free stall barn with concretefloored alleys. The stalls were located side by side in rows of 6 stalls; there were 12 stalls per room. During the experiment, access to some of the stalls was closed to provide 1 stall for each cow in the different sized test groups. The animals were kept in these barns from November to April in yr 1 (24 cows, temperature 1.75 $\pm 5.45^{\circ} \mathrm{C}$ from warmest $23.5^{\circ} \mathrm{C}$ to coldest $-17.7^{\circ} \mathrm{C}$ ), January to June in yr $2\left(18\right.$ cows, $5.97 \pm 8.50^{\circ} \mathrm{C}$ from $29.6^{\circ} \mathrm{C}$ to $-22.3^{\circ} \mathrm{C}$ ), and November to June in yr 3 (10 cows, $4.18 \pm 7.73^{\circ} \mathrm{C}$ from $25.3^{\circ} \mathrm{C}$ to $-18.1^{\circ} \mathrm{C}$ ).

Behavior. The behavior of the cows was recorded by video. One camera (black and white with wide-angle lens 3 to $8 \mathrm{~mm}, 0.8466 \mathrm{~cm}$ CCD matrix) was placed to cover each whole row of stalls. The camera was placed $7.4 \mathrm{~m}$ from the nearest stall. An extra camera was placed to record the alleyways and feed bunks. All cameras were fed into a single video recorder (Sanyo TLS1500P, Osaka, Japan) using a multiplexer. To be able to identify the cows, animals with very similar color patterns were marked using hair coloring.

During the first week after introduction to the experimental barn, the cows were filmed for $24 \mathrm{~h}$ at $\mathrm{d} 1,3$, and 5. After this period, the cows were filmed either 1 $\mathrm{d} / \mathrm{wk}$ (yr 1) or $1 \mathrm{~d}$ every second week ( $\mathrm{yr} 2$ and 3 ) for a total of eleven to eighteen 24-h observation periods per cow. The 2 groups at each year were filmed simultaneously. One observer analyzed the videos and recorded the total duration and the frequency of lying down, as well as duration of lying bouts, using continuous observation.

Injury, Hoof Health, and Cleanliness. Injuries to the legs and hoof health were scored once at the beginning and once at the end of the experiment. Swelling of the front knees was recorded by measuring the circumference of the knees using a tape measure. Lesions of back leg hocks were scored for size and severity. The size of the lesions was measured in 2 directions at right angles, and the results were converted to an area of an ellipse. The severity of the lesions was scored using a 6 -point scale $(0=$ no lesion; $1=$ some hair loss or broken hairs; 2 = bare skin visible with alopecia; $3=$ thickening of skin, calluses; $4=$ reddening of skin; $5=$ open cuts). The hoof health of cows was evaluated at the beginning and end of the experiment (for yr 1 and 3 only) by an experienced veterinarian and hoof trimmer during hoof trimming. The presence or absence of claw diseases: occurrence of sole hemorrhages, laminitis, heel horn erosion, white line disease, sole ulcer, corkscrew claw $\left(>90^{\circ}\right)$, and other rare cases was scored separately on both claws on each leg. The results were compiled by 
giving 1 point for each claw half that had any of those claw diseases. Thus, each diseased claw half counted for 1 , and maximum score for a cow was 8 .

The cleanliness of the cows was evaluated once weekly during the last $7 \mathrm{wk}$ of the experiment using a measuring system adapted from Haley et al. (2000). The teats, other parts of the udder, belly, sides of belly, and legs (lower leg, mid leg, upper leg, on left and right back legs) were evaluated separately, assigning 1 point for each area if there was any dirt or manure visible, giving a maximum possible value for each cow at each week of 10 . The average score for each cow was calculated over the $7 \mathrm{wk}$.

The cleanliness of the stalls was evaluated using a 2 -point scale $(0=$ manure in the stall with combined diameter $<20 \mathrm{~cm}, 1=$ manure in the stall with combined diameter of $>20 \mathrm{~cm}$ ) twice daily, before the stalls were cleaned $2 \mathrm{~d} / \mathrm{wk}$ during the last $4 \mathrm{wk}$ of the experiment. The values were summed together to give a maximum possible value for each stall of 16 .

Statistical Analysis. The total duration of time spent lying, the mean duration, and the frequency of bouts of lying down were analyzed separately for the adaptation week (d 1, 3, and 5) and for the subsequent observation period of 20 to $27 \mathrm{wk}$ using a mixed model. The model for the adaptation period included the type of stall flooring material, year of experiment, and parity as fixed factors and day as a repeated measurement as well as interactions (material by year, material by day) as fixed factors. For the observation period, the average amount of time spent lying down, the mean bout duration, and the frequency of bouts of lying down per day were calculated and used in the model. The model for the observation period included type of stall flooring, year of experiment, parity, and the interaction between material and year.

Mann-Whitney tests were used to test whether there were differences between materials in the dirtiness of stalls or cows, the severity of lesions of the hocks, and the hoof lesions (using the difference between the score at the end of the experiment and the score at the beginning of the experiment). A repeated measure GLM was used to test the difference between the 2 materials in changes in circumference of the front knees. In the model, day and leg (right or left) was used as withinanimal factors and stall flooring material as a betweenanimal factor. Repeated measures of ANOVA with day and leg (right or left) as within-animal factor and material as between-animal factor was used to test for the difference between the 2 materials in changes of hock lesion size during the experiment.

All statistical analyses were conducted using SPSS statistical program (version 13.0 for mixed model and version 12.0.1 for the rest of the analysis; SPSS Inc.,
2005, Chicago, IL). Results are presented as means $\pm \mathrm{SE}$.

\section{Experiment 2}

Experiment 2 examined the cow preference for the 2 types of stall flooring material once they had been kept on one type or the other for at least 21 wk.

Animals and Housing. The preference of 27 Friesian dairy cows that had been used in experiment 1 was tested. Fourteen cows (9 from yr 2 and 5 from yr 3 ) had been kept on straw-bedded concrete stalls and 13 cows (8 from yr 2 and 5 from yr 3 ) had been kept on sand stalls. Seven cows were primiparous, and the rest had calved for 2 to 7 times.

Procedures. The cows were divided into 10 groups (5 groups of cows previously on straw and 5 groups on sand) with each group consisting of 2 or 3 cows. The cows were placed in a test room that consisted of 1 row of stalls; 3 stalls had concrete flooring with straw bedding and 3 stalls had sand bedding. The different stalls were interspersed. The cows were tested for their preference during $5 \mathrm{~d}$. The cows were filmed the first, third, and fifth days of the preference test for $24 \mathrm{~h}$. One person analyzed all the films and recorded in which stall each cow was lying (rump on the stall floor). Scan sampling was used with 9-min interval using Observer (Noldus Information Technology Inc., Wageningen, the Netherlands). Recordings were always in the same order, whether each stall was occupied or unoccupied and by which cow. A total of 160 observations were gathered for each stall during each $24 \mathrm{~h}$ recording. The average number of lying observations in sand and straw within each group was used in the test. Wilcoxon signed ranks test was used to test the preference of the cows for the 2 materials within each group $(n=10)$ of different previous experience. Unless otherwise indicated the results are presented as mean $\pm \mathrm{SE}$.

\section{RESULTS}

\section{Experiment 1}

Behavior. During the adaptation period, there was an interaction between day and bedding material on the total daily duration of resting $\left(\mathrm{F}_{1,49}=21.00, P<\right.$ 0.001 , Figure 1). On $d 1$, the total duration of resting was lower for cows on sand than on straw. With increasing time, there was an increase in total duration of resting for cows on sand, but no increase for cows on straw. The duration of lying time was affected by parity (Table 1). The frequency of lying bouts during the adaptation period increased for cows on sand with time, but did not change with time for cows on straw (Figure 1, day $\times$ material interaction: $\mathrm{F}_{1,49}=10.85, P<0.001$ ). 

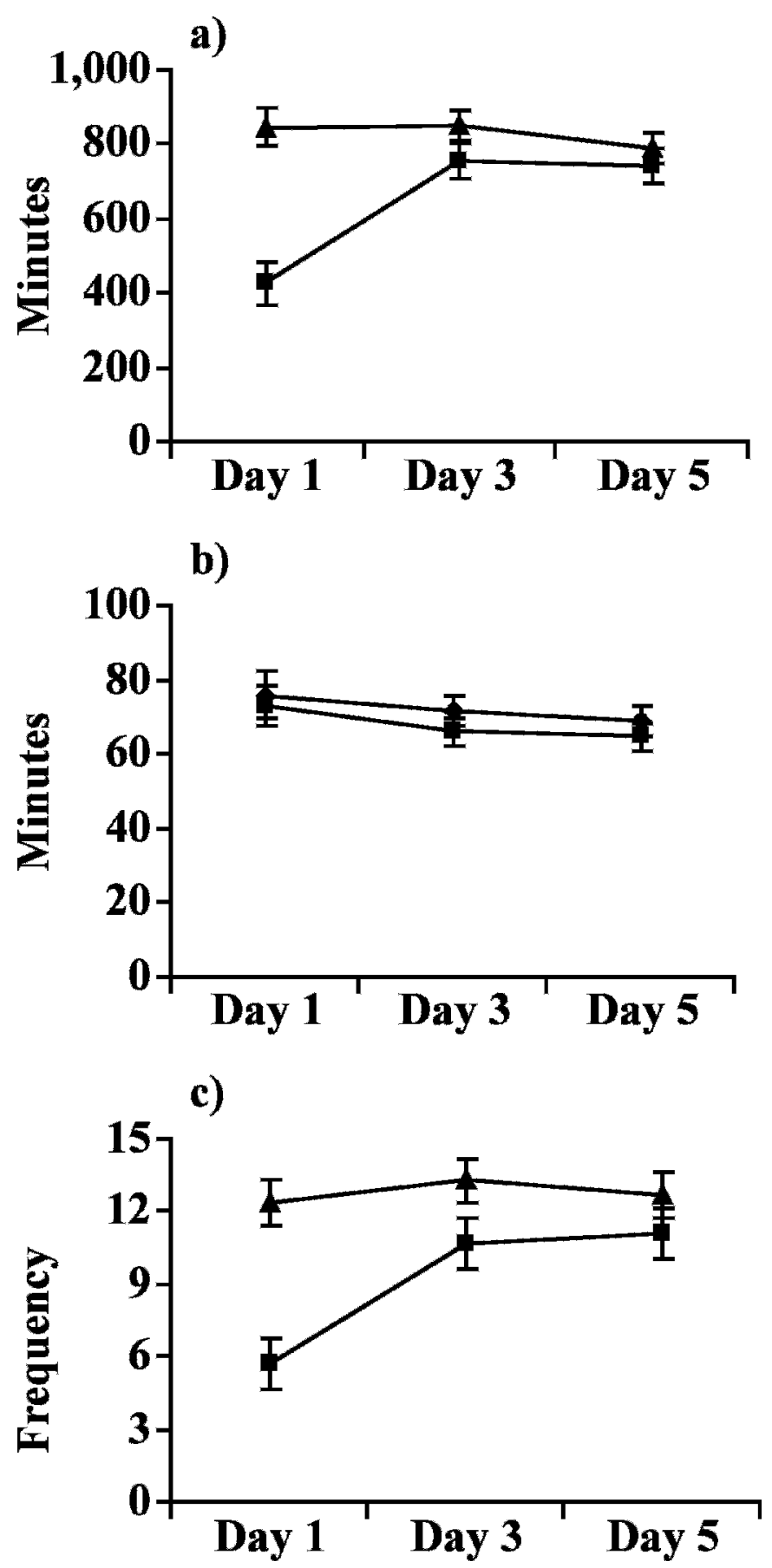

Figure 1. Mean $( \pm$ SE) a) total duration of daily lying times, b) mean duration of lying bouts, and c) frequency of lying bouts in the beginning of experiment on 52 cows using straw-bedded $(\boldsymbol{\Delta})$ concretebased stalls or sand ( $\mathbf{\square})$ stalls. a) There was an interaction between day and bedding material on the total daily duration of resting $(P<$ 0.001). b) There was no difference between materials in the mean bout duration of lying bouts. c) The frequency of lying bouts increased for cows on sand, but did not change with time for cows on straw ( $P$ $<0.001)$.
Table 1. Daily duration of resting on 52 cows of different parities ${ }^{1}$

\begin{tabular}{lcc}
\hline Parity & $\begin{array}{c}\text { During adaptation } \\
\text { week }\end{array}$ & $\begin{array}{c}\text { During subsequent } \\
\text { observation period }\end{array}$ \\
\hline 1 & $596 \pm 43$ & $652 \pm 17^{\mathrm{a}}$ \\
2 & $638 \pm 54$ & $679 \pm 22$ \\
3 & $775 \pm 42$ & $733 \pm 17^{\mathrm{b}}$ \\
4 & $699 \pm 62$ & $749 \pm 25^{\mathrm{b}}$ \\
5 & $682 \pm 113$ & $813 \pm 46^{\mathrm{b}}$ \\
6 & $897 \pm 115$ & $740 \pm 47$ \\
7 & $669 \pm 169$ & $629 \pm 69$ \\
\hline
\end{tabular}

${ }^{\mathrm{a}, \mathrm{b}}$ Indicates significant differences.

${ }^{1}$ Daily lying time was affected by parity during adaptation period of 1 wk $\left(\mathrm{F}_{6,40}=2.63, P<0.05\right)$ and during subsequent observation period of 20 to $27 \mathrm{wk}\left(\mathrm{F}_{6,40}=4.35, P=0.002\right)$.

There was no difference between materials or the interaction between day and material in the mean bout duration of lying bouts $(P>0.10)$. The duration of lying time $(1 \mathrm{yr}, 819 \pm 49 \mathrm{~min} ; 2 \mathrm{yr}, 671 \pm 48 \mathrm{~min} ; 3 \mathrm{yr}, 711 \pm 54$ $\min ; \mathrm{F}_{2,40}=4.50, P<0.05$ ) and frequency of lying ( $1 \mathrm{yr}$, $12.3 \pm 1.1 \mathrm{~min} ; 2 \mathrm{yr}, 9.2 \pm 1.0 \mathrm{~min} ; 3 \mathrm{yr}, 11.4 \pm 1.2$ min; $\left.\mathrm{F}_{2,40}=3.83, P<0.05\right)$ were affected by the year of experiment.

During the remaining observation period of 20 to 27 wk, the daily duration of lying was longer for cows on straw (749 $\pm 16 \mathrm{~min})$ than for cows on sand $(678 \pm 19$ $\min ; \mathrm{F}_{1,40}=13.22, P=0.001$ ). This appeared as a result of a combination of a higher frequency of lying bouts and an increase in the duration because neither one alone differed between the materials (straw vs. sand: bout frequency $10.3 \pm 0.5$ vs. $10.1 \pm 0.6 \mathrm{~min}, P=0.76$; bout length $75.8 \pm 3.2$ vs. $72.3 \pm 3.8 \mathrm{~min}, P=0.38$ ). The total duration of resting was affected by parity (Table $1)$. The year of experiment had an effect on lying duration (1 yr, $754 \pm 20 \mathrm{~min} ; 2 \mathrm{yr}, 701 \pm 20 \mathrm{~min} ; 3 \mathrm{yr}, 687$ \pm 22 min; $\left.F_{2,40}=4.87, P<0.05\right)$ and lying bout length $(1 \mathrm{yr}, 82.0 \pm 4.1 \mathrm{~min} ; 2 \mathrm{yr}, 71.8 \pm 4.0 \mathrm{~min} ; 3 \mathrm{yr}, 68.3 \pm$ $\left.4.5 \mathrm{~min} ; \mathrm{F}_{2,40}=4.70, P<0.05\right)$. No other effects or interactions were significant for any variable.

Cleanliness. The stalls were dirty (at least area of $20 \mathrm{~cm}$ diameter covered with manure) during $16 \%$ of observations, and there were no differences in the dirtiness of stalls between the materials $(P=0.51)$. The cows using straw stalls were dirtier than cows using sand stalls [median and interquartile range, 6.04 (5.39 to 6.28 ) vs. 4.19 (3.62 to 5.16), respectively, $P<0.001$ ]. The difference was most prominent in midlegs [straw, 1.43 (1.14 to 1.84 ) vs. sand, 0.57 ( 0.29 to 0.97$), P<$ 0.001], upper legs [straw, 0.71 (0.29 to 0.86$)$ vs. sand, 0.29 (0.14 to 0.57 ) $P=0.033$ ], and belly [straw, 0.57 (0.25 to 0.86$)$ vs. sand, 0.14 (0.14 to 0.40$) P=0.002$ ].

Injury and Hoof Health. There were no differences between the cows housed on the 2 materials in changes of circumference of the knees during the experiment $(P=0.27)$ or the change in the size of hock lesions $(P=$ 
Table 2. Mean ( $\pm \mathrm{SE})$ hock lesion size of back legs, the median (interquartile range) for severity scores of hock lesions on cows using straw-bedded or sand stalls in the beginning and end of at least a 21-wk experiment

\begin{tabular}{lccccc}
\hline & \multicolumn{2}{c}{ Straw } & & \multicolumn{2}{c}{ Sand } \\
\cline { 2 - 3 } \cline { 5 - 6 } Trait & Beginning & End & & Beginning & End \\
\hline${\text { Lesion size, } \mathrm{mm}^{2}}^{2}$ & $709.71(129.99)$ & $517.61(112.95)$ & & $719.65(139.21)$ & $255.23(75.80)$ \\
Lesion severity $^{1}$ & $2.00(1.00$ to 3.00$)$ & $1.00(1.00 \text { to } 2.00)^{\mathrm{a}}$ & & $2.00(1.00$ to 3.00$)$ & $0.50(0.00 \text { to } 1.00)^{\mathrm{b}}$ \\
\hline
\end{tabular}

${ }^{\mathrm{a}, \mathrm{b}}$ Indicates significant differences.

${ }^{1}$ Lesion severity scores on scale 0 to 5 , where $0=$ healthy.

0.37). The severity of the hock lesions was reduced over time $(P<0.001)$, and there was an interaction between time and material in hock lesion size $(P=0.04)$. At the end of experiment, the severity of hock lesions was lower for cows on sand than for cows on straw $(P<$ 0.001; Table 2).

The change in overall hoof health scores over the observation period (end - beginning) was greater for cows kept on sand (median, interquartile range) -2.00 $(-3.75$ to -0.25$)$ compared with cows kept on straw $[0.00$ $(-2.00$ to $2.00 ; P=0.015)]$. The types of claw lesions are shown by number of claw halves found with each type of lesion (Table 3). The healing was detectable in all types of lesions (hemorrhages and infectious claw diseases).

Experiment 2. Cows having concrete flooring with straw bedding as their previous bedding material preferred to lie in stalls with straw bedding throughout the whole 5 -d test period ( $P=0.043$, Figure 2$)$. On d 1 , cows that previously were kept on sand preferred to lie on straw $(P=0.043)$. But on $d 3$ and 5 they did not show a preference.

\section{DISCUSSION}

The duration of time spent lying was longer when cows had access to straw-bedded stalls than when they had access only to sand-bedded stalls. In addition, cows tended to prefer straw-bedded stalls, especially if they had been kept previously with straw-bedded stalls. Prior familiarity with sand increased the acceptance of sand, but did not lead to greater preference for sand over straw. Despite these effects on behavior, cow cleanliness and hoof health were better for cows kept on sand-bedded stalls.

During the adaptation week at the beginning of the experiment, the cows kept with straw-bedded stalls lay down in the stalls for longer than the cows kept with sand-bedded stalls. This was especially marked during the first day, but the cows adapted rapidly and there was much less of a difference during the subsequent 2 d. This longer resting time was due to a higher frequency of lying bouts on straw than on sand. A similar effect of softer stall flooring in increasing the frequency that cows lay down and stand up was noted previously in tie stalls (Haley et al., 2001; Rushen et al., 2007). In contrast, Cook (2003) suggests that sand may help cows to rise and lie down by improving surface traction in stalls.

A longer duration of lying in straw-bedded stalls was apparent during the reminder of the 27 -wk observation period, but in this case neither the lying bout length nor the lying frequency differed between the bedding materials, indicating that it is a combination of these factors that induce the difference in the total duration of lying down. Our results agree with Natzke et al. (1982), Herlin (1997), and Chaplin et al. (2000b), who found that cows lie down longer on softer materials. Tucker et al. (2003) found that cows preferred sawdust bedding over sand, and Manninen et al. (2002) found

\section{Cows kept on straw $\square$ Sand $\square$ Straw \\ Cows kept on sand 图 Sand $\square$ Straw}



Figure 2. The development of lying preference in a 5-d preference test after at least $21 \mathrm{wk}$ of exposure to 1 of the 2 bedding materials. The first bars describe the average number of lying observations of cows kept on straw-bedded concrete stalls and next bars show the choices of cows kept on sand stalls. Maximum number of observations per $24 \mathrm{~h}$ is 160 . Cows having straw as their previous bedding material preferred straw throughout the test period. On d 1 cows kept on sand preferred to lie on straw, but showed no preference during d 3 and 5. $* P<0.05$. 
Table 3. Changes in hoof lesion score (mean $\pm \mathrm{SE}$ ) of cows using straw or sand stalls in the beginning and in the end of the experiment and types of hoof lesions found with each claw half recorded separately

\begin{tabular}{lccccc}
\hline & \multicolumn{2}{c}{ Straw } & & \multicolumn{2}{c}{ Sand } \\
\cline { 2 - 3 } \cline { 5 - 6 } & Beginning & End & & Beginning & End \\
Item & 17 cows & 17 cows & & 17 cows & 16 cows \\
\hline Hoof lesion score $^{1}$ & $5.00 \pm 0.48$ & $5.29 \pm 0.39$ & & $5.63 \pm 0.51$ & $3.69 \pm 0.34$ \\
Sole hemorrhages $_{\text {Heel horn erosion }}$ & 46 & 49 & & 54 & 41 \\
White line disease & 51 & 51 & 68 & 3 \\
Other & 6 & 6 & 6 & 0 \\
\hline
\end{tabular}

${ }^{1}$ Maximum hoof lesion score is $8 ; 0=$ healthy.

that cows preferred straw bedding over sand. Drissler et al. (2005) observed that the depth of sand bedding decreased with use and its surface became concave, which in turn reduced the total lying time of cows. Still, in our experiment this effect was minimized by regular maintenance of sand stalls.

Nevertheless, whether the reduction in lying time on sand was sufficient to affect the welfare of the animals is not clear: the durations of lying on both sand and straw-bedded stalls were within the range of lying times usually reported (Tucker et al., 2003; Cook et al., 2004). Yet Jensen et al. (2005) have concluded that heifers need 12 to $13 \mathrm{~h}$ of resting time daily. In our experiment the cows on sand were spending $11 \mathrm{~h}$ per day lying down.

Our results confirmed that previous experience plays an important role in the preference for bedding materials. The preference test conducted after exposure to the 2 types of bedding still showed an overall preference of straw; cows familiar with straw bedding showed a strong preference for it, and cows familiar with sand bedding used both materials equally. Tucker and Weary (2004) found that exposure to sand during 2 previous lactations made the sand roughly as desirable as sawdust for lying, but exposure of just a few days did not affect their preference so thoroughly. To attain greater acceptance of sand-bedded stalls, cows need to have time to get used to the material.

Despite these behavioral effects, the cleanliness and hoof health were better for cows kept on sand-bedded stalls than those kept in straw-bedded stalls. There was no difference between the cleanliness of stalls; however, cows in straw stalls were more dirty compared with cows in sand stalls. In addition, hock lesions healed more quickly on cows using sand stalls. The tendency of sand bedding to conform to the body shape of the cows might be the reason for the improved healing because a lying cow can position her leg to avoid pressure on a lesion. Vokey et al. (2001) suggested that less contact with bed surface increased healing. Our results are in agreement with Weary and Taszkun (2000), who found lower incidence of hock lesions on sand than on geotextile mattresses or sawdust and with Vokey et al. (2001) finding best recovery on sand compared with mattress and concrete. Fulwider et al. (2007) found fewer cows with lesions on sand compared with rubber-filled mattresses.

Claw disorders of cows using sand recovered more compared with straw. Our results agree with previous findings (Cook, 2003; Cook et al., 2004; Espejo et al., 2006) of a smaller prevalence of lame cows on sand stall herds compared with mat stalls. Cook (2003) suggests that the benefits of sand as a bedding material may come from its ability to increase stall use and recumbency time. Nevertheless, according to our results, the improved claw health on sand stalls was not due to an increased time spent lying down in sand stalls. In contrast, the reduced hoof health of cows using straw bedding might have been responsible for the increased lying time of cows kept on straw-bedded stalls because lame cows spent more time lying down (Singh et al., 1993b; Galindo and Broom, 2002; Juarez et al., 2003). The connection between claw health, injuries, and daily lying time is complex; claw lesions were associated with reduced lying time (Singh et al., 1993a; Chaplin et al., 2000a; Cook et al., 2004). Singh et al. (1994) suggested that longer lying period may be important for the prevention of lameness. Nevertheless, in our experiment, sand bedding improved hoof health and reduced time spent lying.

In conclusion, whereas cows preferred straw to sand bedding and lay down longer on straw, cleanliness and hoof health were better on sand, suggesting an improvement in overall welfare. The complex correlations between lying time and hoof health make it difficult to interpret lying time alone as a measure of the effect of stall design on animal welfare unless we understand the reasons for the differences in time spent lying down.

\section{ACKNOWLEDGMENTS}

The authors wish to thank Jouni Niemi (Vetman Ltd.) for hoof health scoring, Sakari Alasuutari (University 
experimental farm) for excellent assistance at the experimental farm, the Walter Ehrstrm fund, and the Finnish Ministry of Agriculture and Forestry for funding.

\section{REFERENCES}

Chaplin, S. J., H. E. Ternent, J. E. Offer, D. N. Logue, and C. H. Knight. 2000a. A comparison of hoof lesions and behaviour in pregnant and early lactation heifers at housing. Vet. J. 159:147-153.

Chaplin, S. J., G. Tierney, C. Stockwell, D. N. Logue, and M. Kelly. $2000 \mathrm{~b}$. An evaluation of mattresses and mats in two dairy units. Appl. Anim. Behav. Sci. 66:263-272.

Cook, N. B. 2003. Prevalence of lameness among dairy cattle in Wisconsin as a function of housing type and stall surface. J. Am. Vet. Med. Assoc. 223:1324-1328.

Cook, N. B., T. B. Bennett, and K. V. Nordlund. 2004. Effect of free stall surface on daily activity patterns in dairy cows with relevance to lameness prevalence. J. Dairy Sci. 87:2912-2922.

Drissler, M., M. Gaworski, C. B. Tucker, and D. M. Weary. 2005. Freestall maintenance: Effects on lying behaviour of dairy cattle. J. Dairy Sci. 88:2381-2387.

Espejo, L. A., M. I. Endres, and J. A. Salfer. 2006. Prevalence of lameness in high-producing Holstein cows housed in freestall barns in Minnesota. J. Dairy Sci. 89:3052-3058.

Fisher, A. D., G. A. Verkerk, C. J. Morrow, and L. R. Matthews. 2002. The effects of feed restriction and lying deprivation on pituitaryadrenal axis regulation in lactating cows. Livest. Prod. Sci. 73:255-263.

Fulwider, W. K., T. Grandin, D. J. Garrick, T. E. Engle, W. D. Lamm, N. L. Dalsted, and B. E. Rollin. 2007. Influence of free-stall base on tarsal joint lesions and hygiene in dairy cows. J. Dairy Sci. 90:3559-3566.

Galindo, F., and D. M. Broom. 2002. The effects of lameness on social and individual behaviour of dairy cows. J. Appl. Anim. Welf. Sci. 5:193-201.

Haley, D. B., A. M. de Passillé, and J. Rushen. 2001. Assessing cow comfort: Effects of two floor types and two tie stall designs on the behaviour of lactating dairy cows. Appl. Anim. Behav. Sci. 71:105-117.

Haley, D. B., J. Rushen, and A. M. de Passillé. 2000. Behavioural indicators of cow comfort: Activity and resting behaviour of dairy cows in two types of housing. Can. J. Anim. Sci. 80:257-263.

Herlin, A. H. 1997. Comparison of lying area surfaces for dairy cows by preference, hygiene and lying down behaviour. Swedish J. Agric. Res. 27:189-196.

Jensen, M. B., L. J. Pedersen, and L. Munksgaard. 2005. The effect of reward duration on demand functions for rest in dairy heifers and lying requirements as measured by demand functions. Appl. Anim. Behav. Sci. 90:207-217.
Juarez, S. T., P. H. Robinson, E. J. DePeters, and E. O. Price. 2003. Impact of lameness on behaviour and productivity of lactating Holstein cows. Appl. Anim. Behav. Sci. 83:1-14.

Manninen, E., A. M. de Passillé, J. Rushen, M. Norring, and H. Saloniemi. 2002. Preferences of dairy cows kept in unheated buildings for different kind of cubicle flooring. Appl. Anim. Behav. Sci. 75:281-292.

Munksgaard, L., M. B. Jensen, L. J. Pedersen, S. T. Hansen, and L. Matthews. 2005. Quantifying behavioural priorities - Effects of time constraints on behaviour of dairy cows, Bos taurus. Appl. Anim. Behav. Sci. 92:3-14.

Munksgaard, L., and H. B. Simonsen. 1995. Behavioural and pituitary-adrenal axis responses of tethered cows or cows kept in pens with slatted floors. Acta Agric. Scand. Sect. Anim. Sci. 45:132138.

Natzke, R. P., D. R. Bray, and R. W. Everett. 1982. Cow preference for free stall surface material. J. Dairy Sci. 65:146-153.

Rushen, J., D. Haley, and A. M. de Passillé. 2007. Effect of softer flooring in tie stalls on resting behavior and leg injuries of lactating cows. J. Dairy Sci. 90:3647-3651.

Singh, S. S., W. R. Ward, K. Lautenbach, J. W. Huges, and R. D. Murray. 1993a. Behaviour of first lactation and adult dairy cows while housed and at pasture and its relationship with sole lesions. Vet. Rec. 133:469-474.

Singh, S. S., W. R. Ward, J. W. Huges, K. Lautenbach, and R. D. Murray. 1994. Behaviour of dairy cows in a straw yard in relation to lameness. Vet. Rec. 135:251-253.

Singh, S. S., W. R. Ward, K. Lautenbach, and R. D. Murray. 1993b. Behaviour of lame and normal dairy cows in cubicles and in a straw yard. Vet. Rec. 133:204-208.

Tucker, C. B., and D. M. Weary. 2004. Bedding on geotextile mattresses: How much is needed to improve cow comfort? J. Dairy Sci. 87:2889-2895.

Tucker, C. B., D. M. Weary, and D. Fraser. 2003. Effects of three types of free-stall surfaces on preferences and stall usage by dairy cows. J. Dairy Sci. 86:521-529.

Tuyttens, F. A. M. 2005. The importance of straw for pig and cattle welfare: A review. Appl. Anim. Behav. Sci. 92:261-282.

Vokey, F. J., C. L. Guard, H. N. Erb, and D. M. Galton. 2001. Effects of alley surface on indices of claw and leg health in dairy cattle housed in a free-stall barn. J. Dairy Sci. 84:2686-2699.

Ward, W. R., J. W. Hughes, W. B. Faull, P. J. Cripps, J. P. Sutherland, and J. E. Sutherst. 2002. Observational study of temperature, moisture, $\mathrm{pH}$ and bacteria in straw bedding, and faecal consistency, cleanliness and mastitis in cows in four dairy herds. Vet. Rec. 151:199-206.

Weary, D. M., and I. Taszkun. 2000. Hock lesions and free-stall design. J. Dairy Sci. 83:697-702.

Zdanowicz, M., J. A. Shelford, C. B. Tucker, D. M. Weary, and M. A. G. von Keyserlingk. 2004. Bacterial populations on teat ands of dairy cows housed in free stalls and bedded with either sand or sawdust. J. Dairy Sci. 87:1694-1701. 